\title{
Admiral Antonio Barceló, 1716-97: A Self-Made Naval Leader
}

\author{
Agustín Ramón Rodríguez González
}

Real Academia de la Historia, Madrid

The career of Antonio Barceló y Pont de la Terra has on many occasions attracted the attention of researchers and publishers of naval history. He was a modest mail-boat skipper, who, despite not being a nobleman and having very little academic training, managed to obtain the title of Admiral (Teniente General de la Armada) at a time when such an achievement was nigh on impossible. It was solely due to his merits in action during times of war and other outstanding services. ${ }^{199}$

Much less attention has been paid to the perhaps inevitable fact, given his character and career, that despite being an outstanding leader in the Spanish Royal Navy at that time, prejudices of all kinds, professional envy and the inertia of the 'establishment' ensured that a large part of his efforts did not receive their due reward and his ideas were not applied, or at least not to the desired extent.

Perhaps one of the subtlest attacks on his career and legacy has been to trivialise his actions, presenting them as typical of a hard, skilled 'corsair', within a very limited operational context, based on anecdotal evidence. This chapter aims to correct or, at least, considerably clarify this accepted opinion.

\section{How to cite this book chapter:}

Rodríguez González, A R. 2017. Admiral Antonio Barceló, 1716-97: A Self-Made

Naval Leader. In: Harding, R and Guimerá, A (eds.). Naval Leadership in the Atlantic World. Pp. 107-115. London: University of Westminster Press. DOI: https://doi.org/10.16997/book2.k. License: CC-BY-NC-ND 4.0 


\section{Barcelós career}

A brief summary of the career of this great sailor would not be amiss, as he was a very well-known figure who, in our opinion, did not receive due credit. Born in Palma de Mallorca on 31 December 1716, in June 1735 he was appointed by Royal Order as master of the mail boat that connected Palma with Barcelona, giving him at the tender age of 18 a position he had already held whenever his father, from whom he inherited the boat and position, was absent or ill.

In November 1738, at 21 years old, he was rewarded with promotion to Lieutenant Junior Grade (Alfarez de Navio) for the bravery and skill with which he repelled an attack by two Algerian galiots during one of his crossings. Another of his services was to supply Palma with bread and flour during a severe 'supplies crisis', during which, to encourage his crew to work faster and to gain more cargo space on board, he got rid of the water tank. He rose to Sub-lieutenant (Teniente de Fragata) in May 1748. He also took command of a squadron of armed privateering xebecs, which had to act together with the navy ships against the Barbary corsairs, but the results were poor due to bureaucratic problems, indolence and a lack of coordination.

In June 1753 he was promoted to effective Lieutenant, as a result of repelling the attack of two Algerian galiots with his xebec, capturing one and damaging the other one until it fled. After 15 years, during which his bravery could have been put to much better use, our man entered the Spanish Royal Navy through well-earned references, at the unusually old age of 39 years old.

In August 1753 he was promoted to acting Lieutenant (Teniente de Navío) after providing another outstanding service which he combined with his postal duties: with his xebec and another under his command, he managed to capture an Algerian galiot and burn a Majorcan ship the Algerian privateers had just seized.

There followed some years of relative obscurity for Barceló, in which we have not been able to find any relevant services or promotions. Perhaps this was due to the difficulty for such an unusual sailor in the Royal Navy to gain acceptance, not to mention his service in the xebec, which became an efficient antidote to the similar Barbary ships and galiots, rather than the more prestigious ships of the line or frigates in royal service.

Nevertheless, Barcelós continuous successes between 1762 and 1769 confirmed that too much time had been lost in accepting the obvious: during those seven years, Barceló, at the helm of his xebec, accompanied by one or several others, captured or destroyed no fewer than 19 Barbary corsairs, of 6 to 30 guns, with a total of 1,600 prisoners, and freeing almost 1,000 Christian captives of all nationalities.

In order to better understand this, we have to remember that these Barbary sailors were not armed merchants, who defended themselves more or less weakly, but corsairs who literally fought to the death because, among other 
reasons, they knew there would be no exchange of prisoners for them and they could only hope for a short, difficult life of hard labour.

This series of successes was accompanied by the corresponding promotions for Barceló. He became Commander (Capitán de Fregata) in June 1762 and Post Captain (Capitán de Navío) in March 1769. The successes continued: such as on 22 October 1769, for instance, with a division of six xebecs, another 4-gun Algerian ship was conquered and captured near Melilla. That same year, on 24 November, a pension of 12,000 reales annually for life was granted by Royal Order for his outstanding services. In February 1775, Barceló rose to Commodore [Brigadier]. ${ }^{200}$

His expertise in that style of naval warfare was more than proven, as was his personal courage, shown by several wounds, one of which was a very serious shot to his mouth that ripped out several teeth and became infected. He had a high temperature and could not eat or drink for almost three months, but he remained in charge of his xebec on a patrol mission. Whether due to the difficulty of his constant services or for other reasons, he was also said to be extremely deaf, yet despite this he remained in active service.

In the same year as he was promoted to Commodore, Barceló took part in the unfortunate expedition against Algiers. He was in command of a division of xebecs, with nine ships of between 20 and 32 guns, as well as the squadron and convoy, under the overall command of Teniente General don Pedro González Castejón for the naval part and Conde O'Reilly for the landing party. Barceló criticised the actions taken by these two commanders for landing on a beach near the corsairs' port, but they did not pay any attention to him. However, when the situation for the landing party became critical, Barceló did not wait for orders and covered the threatened flank of troops by firing from his xebecs, whilst Jefe de Escuadra Juan Acton did the same on the opposing flank with other units, thus avoiding greater disaster.

Spanish public opinion severely criticised the commanders for their ineptitude, and praised Barceló, who shortly after was promoted to Rear Admiral (Jefe de Escuadra). But this reward, and the fact he received so much praise and had exposed the ineptitude of senior officers, made him many enemies, with unpleasant consequences, not so much for his career - although it had some effect - but rather in terms of the influence of his leadership.

In spite of everything, he had risen to Rear Admiral by April 1779, in time to be involved in a new dispute against a very different type of enemy: the British Royal Navy.

His new mission was to take light blockade forces to Gibraltar, to oppose the British squadron there under the command of Rear Admiral Robert Duff. A blockade was always tedious, and more likely to highlight virtues such as patience and tenacity than brilliant acts of strategy and courage. On the other hand, completely closing the Strait, with its typical weather conditions, to any ship, whether an enemy or neutral, was an almost impossible task during the age of sail. The situation was made worse by the usual damage and operational 
withdrawals in Barcelós fleet, and above all the impatience and inexperience of the commanders and officers of the army entrenched at La Línea. Thus criticism rained down on Barceló, aggravated by the failure of his attack with a fireship, to such an extent that he was put under the inspection of another admiral, Rodríguez de Valcárce, a situation that was both embarrassing and wrong.

Such a harsh judgement was not meted out against other Spanish leaders who, for one reason or another, let three successive large convoys pass during the war and the siege. Each had been guarded by powerful squadrons and was much more important and decisive for the fortune of the besieged town than any small ship that managed to enter port, which is all that Barceló could be reproached with. However, the leaders who commanded squadrons were not reproached in any way; some were even promoted, such as Lángara, despite losing a large part of his own squadron in a battle against Admiral Rodney's squadron on 16 January 1780.

Barcelós difficult situation is corroborated in a letter sent from the Court to the new Commander-in-Chief, the Duke of Crillón, informing him that Barceló, due to his advanced age, deafness and limited academic training, was not a trustworthy leader. ${ }^{201}$

But while they lost ships, money and men with the controversial 'floating batteries' designed by the French engineer D’Arçon, which had such an unfortunate end, Barcelós luck began to change. He had the idea of designing gunboats to bombard the town from the sea. These were large rowing boats armed with a 24-pounder cannon and reinforced, first with cork and later with iron, although it was soon discovered that this overloaded the boat unnecessarily. These gunboats were particularly useful in the night attacks against Gibraltar, probably being the weapon that most concerned and disturbed the besieged. However, there were never enough of them, partly due to focusing on the batteries, and partly from pure indolence.

And so it was that, once the war ended, the King was satisfied with Barcelós tireless service. He had been continuously in action, and he was promoted on 16 February 1783 to Admiral Teniente General as part of a big promotion, justified because the war was deemed to be a victory, with the exception of Gibraltar. It must be said that of the four main promotions, the minister Floridablanca stated in a letter to Crillón that Barcelós was the most deserving, and reminded the Duke of Crillón that, despite reports discrediting Barceló, Crillón himself had been the most interested in Barcelós promotion.

Once the war with Great Britain had ended, interest was reignited in the continuing war with Barbary corsairs. Barcelós system was so effective that both Tripoli and Tunisia decided to sign a peace treaty with Spain. Only Algiers continued the fight, despite the Arab commanders or corsair captains insisting that their mission was now almost impossible.

It was obvious that only a masterstroke could dissuade Algiers from continuing with its policy of confrontation, and Barceló was given command of 
that mission. Believing that a new landing like that of 1775 was excessively expensive and dangerous, he planned a systematic bombardment of the town and port with his gunboats and newer types, such as bomb-ships armed with howitzers. They were trained in boarding to repel the counter-attack of the light enemy boats. All were guarded by ships of the line, frigates, the inevitable xebecs and many others.

The squadron of 85 vessels subjected Algiers to a series of nine heavy bombardments in July 1783. Despite serious damage and very few Spanish losses, Algiers did not cede and the expedition had to be repeated the following year, on a larger scale and with support from galleys of the Knights of St John of Malta and vessels from the kingdoms of Naples and Portugal joining for the first time. Despite his age, Barceló was personally involved to such an extent, covering the line of fire aboard a felucca, that his ship was in serious danger of being hit by an enemy projectile and sinking, despite which the bombardments continued.

The tactics that he used were as severely criticised by some as they were celebrated by others who had not forgotten the disaster of 1775 . He was completely successful: Algiers could not hold up against such a series of attacks indefinitely, which besides the damage they caused (always limited due to the artillery of the time), forced Algiers to focus all its efforts on defence, and not on privateering, which was its way of life. Thus, after preliminary talks, and faced with the threat of a third expedition, peace was signed in 1786, one of the Spanish envoys being none other than José Mazarredo, who had been under Barcelós orders during the attacks. ${ }^{202}$

Although relations with Algerian corsairs in particular, and the Berbers in general, had some flare-ups over the following years, they were no longer the threat they had been to Spain since the sixteenth century. This enabled the repopulation of the east coast from Catalonia to Granada, and the significant economic boom of this region, which had previously been under threat of corsairs. It was definitely the most important and decisive Spanish victory of the eighteenth century.

Despite this, Barceló was barely rewarded, except for the confirmation of his promotion to Admiral and the award of the Grand Cross of the Order of Charles III, as well as other minor rewards. No doubt the reason was that he could only rise further to become Admiral of the Navy, a title that many of the Courtiers deemed excessive for his humble origins.

The last few years of his life passed uneventfully, with the exception of being passed over for command of a similar expedition, although much smaller, against Morocco, which was given to Francisco Morales de los Ríos, an inept man, who had been previously disqualified due to his cowardice as second-incommand of the frigate Hermione (26), which was lost in battle with a British frigate in May 1762. Nevertheless, Morales was promoted and given the title of Count of Morales for his small bombardment of Tangiers, which was a skirmish compared with those in Algiers. Morales was to demonstrate this 
ineptitude again in the Battle of San Vicente in February 1797, but his career shows the significant difference in treatment that officers could experience.

Barceló died from natural causes in his home in Palma on 30 January 1797, a fortnight before Morales's failure in San Vicente that led to him being dismissed from the service and demoted.

\section{Xebecs: a tough school for sailors}

Nicholas Rodger reminded us some time ago that most eighteenth-century sailors on men-of-war had a strange profession as they only worked during wars. Once peace was achieved, all the navies stripped the ships of the rigging and sails, cannons and equipment, and anchored them in the dockyards, with very few small ones staying in active service, exclusively for scientific exploration and surveillance tasks.

But that was not the case for the xebecs, at least until the Treaty of 1786: they continually patrolled in search of their slippery and dangerous enemies, the Barbary corsairs, staying in port only for essential work such as repairs or renewing supplies and ammunition. Therefore it was a formidable school for young officers who, instead of settling on land in more or less bureaucratic postings, had the chance to learn and grow in their profession.

To cite two well-known names, none other than Federico Gravina and Antonio Escaño carried out many of their first battles and campaigns in xebecs, directly under Barcelós command or under his inspiration and protection. Gravina, a modest ensign (alférez de fragata), sailed in Pilar and Gamo, distinguishing himself later in command of the San Luis, in which he began to stand out. He took part in the two bombardments of Algiers, commanding the Catalán and dealing with the intelligence for the expedition. Escaño, a simple midshipman (guardiamarina), was under the direct orders of Barceló on the Vigilante in several battles; then he passed on to the Atrevido and even commanded a division of xebecs under the flag of the frigate Casilda.

Barcelós relationship with these and other great sailors of the time was close, as is shown in a personal letter from Gravina to Barceló upon hearing about his rise to Admiral:

'No one has more reasons than I to celebrate the satisfaction and advantage for Spain... I am most pleased for the promotion you have just received, for which I send you my warmest congratulations.'203

People of the calibre of Escaño, Grandallana and Alsedo, and many others, also wrote in similar terms.

Among these there may also have been the great Mazarredo, who was under Barcelós orders in Algiers, and signed the peace treaty that Barceló won. 
Mazarredo used his gunboats brilliantly to harass the ships blocking Cádiz in 1797. But the many huge merits of this great Basque sailor did not include acknowledging debts to others who were not loyal subordinates.

What was for some a promotion and apprenticeship, was for others a punishment. An officer condemned for dishonourable conduct before the enemy was often offered the chance to 'redeem' himself by voluntarily boarding as an 'adventurer' in the xebecs. Sometimes it was done with entire crews: on one occasion, three Spanish galleons were shamefully beaten by a sole Algerian xebec that captured one and made the other two flee. It was considered that the best way to 'retrain' the crews and officers was to put them under Barceló's command. ${ }^{204}$

It must have greatly surprised these fellow officers to be faced with such a rough and uneducated man, with little culture, who shouted a lot and took off his wig at the slightest occasion. A man who was capable of joining a boarding, or of carrying out an order himself. On one occasion, upon capturing an Algerian ship, orders forbade taking anything from it on board, for fear of an epidemic. A sailor took a liking to a beautiful wide red belt and Barceló himself snatched it out of his hands and threw it into the sea, a gesture that shook his much primmer subordinates, who would have sent a petty officer to do it.

But they soon realised they were with a real 'sea dog', a professional forged by long, hard service, resourceful and with common sense, friendly and modest, who became a legend not just for his crews, but for the whole Spanish east coast, a fact proven by many folk songs and poems. There is no doubt he was the most popular and admired Spanish sailor of the eighteenth century.

Barceló was also a man who took care of his own and did not allow other authorities to interfere with his subordinates, something that is mentioned many times. He dealt with things as a 'family affair'.

As might be expected, Barceló was strongly in favour of meritocracy in promotions and mentions in despatches, in a navy where careers were based on seniority of service and the King's favour. Thus, with his typical frankness, he wrote to Charles III in November 1784, while preparing his third expedition against Algiers:

'But before leaving the Court I find a big obstacle that, no doubt, will make this venture difficult, this being that I will not find officers willing to serve under my orders as there will be no reward no matter how much they risk their life in action. Your Majesty knows better than I that no General among those that have been heroes would have achieved such successful actions if they had not had brave corporals and subordinates who, obeying their orders, earned their deserving rewards through hard work and sweat.'...

'Having seen men promoted who were not there (in the second expedition to Algiers) or, if they were, had only been promoted earlier, am I, 
perhaps, to blame for many recent officers having been put under my command so that after having risked everything, they are not promoted due to a shorter length of service? And if length of service were the only deserving reason, what would be the point of fostering and stimulating young men to attempt glorious actions if they are not going to receive their due reward for a lack of it?'

He summarised:

'How am I to attempt glorious actions for the State when I can see from the start the hurdle of not duly rewarding Your Majesty's vassals, who have tried hard to serve you?'

Finally, he argued that he was the person who best knew which subordinates were the most suitable for the job and which deserved to be rewarded, not the bureaucracy or the narrow regulations. ${ }^{205}$

What Barceló so insistently proposed to King Charles III was little short of revolutionary for the time, and very little or nothing could be done in that sense. However, there is no doubt we are in the presence of a true leader, a man who trained his subordinates, who demanded everything from them and who requested on their behalf the rewards that were their main motivation. And in light of the history of the Spanish navy, many more like Barceló were needed at that time, when efforts were not rewarded, and defeats, including the most shameful, often had little influence in sailors' careers.

\section{Barcelós other activities}

Barceló was not just the leading commander of a new kind of ship, the xebec, and expert in its suitable use, but he was also concerned with design changes: from the originals with around 20 cannons and lateen-rigged (aparejo latino), to the final ones with over 40 guns and with a pole-masted square rig (aparejo redondo de polacra). In this race the Algerians could not match the Spanish, although they tried. Barceló constantly experimented with changes and improvements. Some were carried out at his own expense, such as those called 'galleons', lighter and more streamlined for hunting the enemy. He examined the best among the captured Algerian boats and proposed and obtained their incorporation into the navy.

He also developed the gunboats and their derivatives, creating a weapon that would give the navy many of the modest successes it achieved in the tragic years from 1797 to 1805 , and which later on would be of great importance in the decisive defence of Cádiz from 1810 to 1812 . For all of them he planned tactics that were deemed unorthodox, generally passing from boarding to pounding with artillery. 
However, he also had unusual sensibility and real concern for the service and for people. After the recovery of Menorca in 1783, which had been the Royal Navy's base for many years since the War of Spanish Succession, with the logical benefits for its inhabitants, he was the driving force behind the creation of new buildings in Port Mahón. In a letter to the King he wrote:

'With this, Sir, I promise not only to teach the Moors a lesson, but to favour the locals of Mahón who I see to be somewhat uprooted from that island, as they have not had their main trade and are lacking active business, thus managing to consolidate the serenity of these vassals and their families...' 206

That was not all. Enriched by his many captures, he did not hesitate to invest part of his capital in shipping companies. However, not being interested in money, it is known that he handed out large amounts to the dockyards so they could finish building ships that had been stopped due to a lack of state funding, and he even refused to receive payment for expenses and statutory compensations. This wealth and generosity could well have been another reason for envy among many colleagues. ${ }^{207}$

\section{Conclusion}

The figure of Antonio Barceló, although well-known and popular, has been excessively trivialised, being seen as nothing more than a rough sea dog who beat the Algerian corsairs in epic combats between xebecs. Some of that can be seen in the Spanish navy which regularly gives his name to light units: from torpedo boats to patrol boats.

But as we have seen, Barcelós achievements significantly surpass those achieved by his xebecs and gunboats, providing a much more complete professional image of the man. And that a man with his limitations knew how to train and lead many of the best Spanish sailors of the eighteenth century, who fought to eradicate the damaging system of rewards and punishments of the age, despite which, and on his own merit, he managed to obtain the highest ranks combat after combat, is by no means the least of his contributions.

As the popular folk song says:

'If the King of Spain had

Four like Barceló,

Gibraltar would be Spain.

And for the English, no.'

The fact that this simple verse contained so much truth is something that some would never forgive. 
